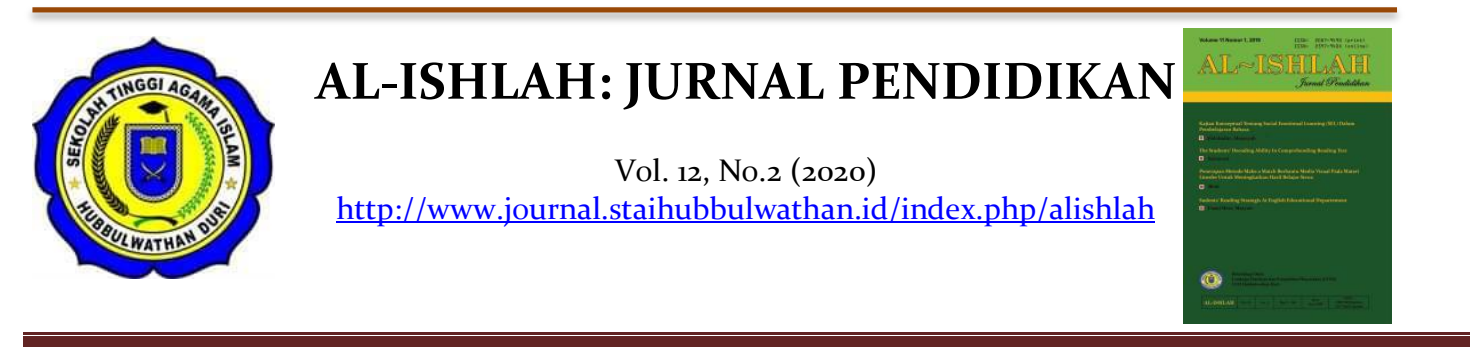

\title{
LEARNERS’ INTEREST IN NEW NORMAL
}

\author{
Setiawati \\ Sekolah Tinggi Agama Islam Hubbulwathan Duri, Riau, Indonesia \\ Email: setiacantik85@gmail.com

\section{Dini Deswarni} \\ Sekolah Tinggi Agama Islam Hubbulwathan Duri, Riau, Indonesia \\ Email: dinideswarni1978@gmail.com

\section{Widia Yunita} \\ Sekolah Tinggi Agama Islam Hubbulwathan Duri, Riau, Indonesia \\ Email: widiayunita@staihubbulwathan.id
}

DOI: 10.35445/alishlah.v12.i2.255

Accepted: October $6^{\text {th }}, 2020$. Approved: December $20^{\text {th }}, 2020$

Published: December $30^{\text {th }}, 2020$

\begin{abstract}
This study aims to know learners' interest with blended learning at new normal period at the second, fourth, and sixth semesters of English Department, Islamic Religion Department, Islamic Banking Department, Islamic community Development Department of STAI Hubbulwathan Duri. This research used quantitative approach. The design of the research was a survey research. Total population was 260 respondents. The undergraduate students have the same qualification and academic background before doing survey. They had ever learned by using blended learning in a new normal situation. Sample of this research was 155 respondents. The total rating percentage of learners' interest in involving in the blended learning was 69.98 $\%$. it was in "agree category". This category showed the respondents' interest in blended learning process. Based on overall mean is 2.82 and standard deviation is 0.54. The respondents agree used to have the blended learning activities in their learning process. It means that the learners' had good interest in their blended learning activities.
\end{abstract}

Keywords: Learners’ Interest, Blended Learning, Pandemic Situation 
Al-Ishlah: Jurnal Pendidikan - ISSN: 2087-949o (p); 2597-940X (e)

Vol. 12, No. 2 (2020)

\title{
MINAT BELAJAR PESERTA DIDIK DI MASA NEW NORMAL
}

\begin{abstract}
Abstak
Tujuan penelitin ini untuk mengetahui ketertarikan pelajar mengikuti pembelajaran dengan blended learning di masa "new normal" pada semester dua, empat, dan enam dari jurusan bahasa inggris, agama, perbankan, dan dakwah STAI Hubbulwathan Duri. Penelitian ini menggunakan pendekatan kuantitatif. Disain yang digunakan dalam penelitian survey. Penelitian ini, penulis didukung dengan penelitian survey. Total populasi 260 orang. Mahasiswa yang mempunyai latar belakang akademik dan kualifikasi sebelum melakukan survey. Mereka telah belajar menggunakan blended leraning di pada masa "new normal". Sampel pada penelitian ini 155 responden. Total rata-rata persentase ketertarikan pelajar dalam menggunakan blended leraning adalah $68.98 \%$. Kategorinya adalah setuju. Kategori ini menunjukan ketertarikan responden dengan menggunakan blended learning dalam proses pembelajaran. Berdasarkan rata-rata semuanya 2.82 dan standar deviasi nya 0.54. responden setuju menggunakan blended learning dalam proses pembelajaran. Ini artinya ketertarikan pelajar dengan menggunakan blended learning pada masa pembaharuan.
\end{abstract}

Kata Kunci: Minat Belajar, Blended Learning, Masa Pandemi

\section{INTRODUCTION}

The development of digital technology has given a great impact on the $21^{\text {st }}$ century challenges faced by the educational institution. The rapid development of technology, communication, and information, especially the internet has become a demand for educators in Indonesia to be able to use it. It is a source of positive learning media in supporting the teaching and learning process. The use of media technology provides benefits for educators and learners to access the materials and interact in face-to-face conventional learning, and also outside the classroom through an online platform. Today in the pandemic period, technological applications seem to be the first in teaching-learning process. The learners use various web- tools, such as Facebook, WA, Edmodo, Padlet, and Google classroom. They live and learn by using technology. Learners are close to computers and the internet, it means that there is a greater possibility for them to be more autonomous and responsible. It is expected that learners are responsible for their courses.

Teaching and learning process are done virtual or online class. One of the most popular methods is called blended learning. This method which is also called Hybrid Learning and includes any combination of learning delivery method including most often face to face instruction with asynchronous and synchronous. Blended learning 
Al-Ishlah: Jurnal Pendidikan - ISSN: 2087-9490 (p); 2597-940X (e)

Vol. 12, No. 2 (2020)

is a relatively new term, emerging in parallel with the development of the $21^{\text {st }}$ century technology. Various definitions of blended learning exist, and commonly in higher education, it is known as a combination of traditional face-to-face teaching, and online teaching. In blended learning, the learners could optimize their face to face learning to learn how to learn in class and then they could enrich their online materials, and do some online instructions/tasks independently anywhere and anytime via online learning apps.

The development of technology to make the education system in Indonesia be better and more advanced to follow other countries. The education system develops from using the conventional system to one that is completely digital. Initially, the teaching and learning process is not bound by time and place. Blended learning is the integration of conventional teaching methods with the digital world. Blended Learning (BL) emerged as one of the most popular pedagogical concepts in higher education and in EFL contexts at the beginning of 2000 (Halverson et al, 2004). This learning model aims to change the culture of teaching-learning which is centered on the teacher (teacher-centered learning) to students (student-centered learning). Learning activities are conducted actively and inactively are more practical than listening to passive lectures in the classroom. In addition, educators take a role as classroom facilitators for students in solving problems Hew and Cheung (2014) said blended learning should be seen as a pedagogical approach that combines face to face with online learning that is able to enhance interaction, not just a mere means of delivering learning.

Blended learning is a scheme to facilitate learning because in the system there is a combination of methods, models, methods in learning so that material can be conveyed effectively in terms of time and energy. In general, it can be concluded that this blended learning model is a combination of the benefits of online learning or (elearning) with face-to-face / (conventional) learning. This is a combination of various aspects from methods, strategy, and learning styles. This learning not to leave interaction and technology.

According to Neumeire (2005) also regarded BL as a combination of face -toface and computer assisted learning in a single teaching and learning environment. In Blended Learning, the learner attends some part of the course in a place outside the house and accompanied by an instructor while the rest is self- learning at his/her own pace through electric, online or the other means at any time and place (Horn \& Staker, 2015; Staker, 2015). Blended learning, face to face learning and online learning vary a lot across different instructional contexts. In the present study, however, blended is defined as the combined instructional. Environment where face- 
Al-Ishlah: Jurnal Pendidikan - ISSN: 2087-9490 (p); 2597-940X (e)

Vol. 12, No. 2 (2020)

to-face learning and online learning are mixed within a single teaching and learning environment. Furthermore, face-to-face learning refers to the traditional classroom instruction where instructors and learners teach and learn face to face in physical classrooms. Online learning, then, refers to web based and self-directed learning either synchronously or asynchronously at computers. This involves the use of various virtual resources and tools such as online learning materials, chat, message boards, net meeting.

In the learning process by using Blended Learning gives several benefits; learning activities can be done in other places so that time can be more efficient. It can facilitate learning activities because this learning make the learners be more cheerful and energy-efficient. The budget for learning can be more efficient because learners usually report on paper and trips to the learning locations can be allocated elsewhere in their activities. By using blended learning, educators and learners can be more flexible in management and time-efficient. It can provide a lot of free time for learners so that educators need to provide encouragement and motivation about the goals and visions that must be achieved in life. This is important because, with so much free time of learners, it can be used for other useful and productive.

Lecturers use blended learning method in teaching - learning process in STAI Hubbulwathan Duri. Blended learning is an alternative method that is highly relevant to the recent digital era, which integrates the traditional methods and methods based on multimedia technology. Blended learning is one of the methods of learning in the knowledge age, where teachers take a role as facilitators, motivators, mentors, and consultants. In STAI Hubbulwathan Duri, lecturers use Google Classroom apps for Asynchronous and Synchronous by using Zoom, Google meets, messenger forum, and FB forum.

Before doing the teaching and learning process the lecturers are given training about apps that are used in an online class. Since in pandemic situation, the process of teaching learning still use blended learning method. Every learners involve in an online class. The learners are involved directly in online learning. Undergraduate students can open the class by using smartphone, and laptop. They can register by using their G-mail account. They follow the class based on the schedule have been determined.

The study from Aulia at al (2020) and Clay (2019) shows positive result in using google classroom as a platform in blended learning. Respondents are actually interested and want to use google classroom. interest is characterized by preference, interest, or pleasure as a form of expression for something that is of interest. Interest has a positive influence on academic learning, domains of knowledge, and specific 
Al-Ishlah: Jurnal Pendidikan - ISSN: 2087-9490 (p); 2597-940X (e)

Vol. 12, No. 2 (2020)

fields of study for individuals, (Hidi, Berndoff, and Ainley, 2002). The interest effects are three important aspects of one's knowledge, namely attention, goals, and learning level (Wang \& Adesope, 2016). In contrast to motivation as a driving factor of knowledge but also as driving factor for attitudes, (Hidi, 2006). Furthermore, the understanding of interest learning is an attitude of obedience to learning activities, both regarding schedule planning learning and the initiative to do the business in earnest (Olivia, 2011).

Furthermore, the learning process has important role in improving quality education, so learning will be more meaningful and useful for students. Therefore, lecturers must pay attention to the better media so that learning is more conducive and meaningful by pointing at modernization activities through technology assistance sophisticated which can help students in understanding the subject matter interactively, effective, and fun. Learning by technological advances, it can provide a significant influence on the education world to support process learning activities. Mastery lecturers and learners in using technology as media is a matter which is very important in order to deal with global competition that demands learners to have an interest in learning so able to be independent, negative, critical thinking and able to solve problems according to demands of the $21^{\text {st }}$ century using learning based on blended learning.

This research is important to do as a consideration for educators to choose the right learning model in this pandemic. It also aims to avoid students' boredom in learning. It is hoped that students will continue to have high motivation to learn during this pandemic.

\section{METHOD}

This research used a quantitative approach. The design of the research was a survey. Kumar (2006) said that survey has been further classified into four categories: (a) Descriptive (b) Analytical (c) School survey and (d) Genetic. Cohen, Lawrence, and Keith (2007) also supported that survey can be descriptive and analytic. This research, the writer conducted descriptive. The total population of undergraduate students of STAI Hubbulwathan Duri was 260 from four majors; English Department, Islamic Religion Department, Islamic Banking Department, Islamic community Development Department. In this research, semester eighth was involved because they did not follow the process of learning by using Blended Learning. The undergraduate students have the same qualification and academic background before doing a survey. They had ever learned through the blended learning activities. The writer took 155 respondents as sample in this research. 
Al-Ishlah: Jurnal Pendidikan - ISSN: 2087-949o (p); 2597-940X (e)

Vol. 12, No. 2 (2020)

The technique of data collection the writer had collected the data by using questionnaires. It is supported by Kumar (2006) who said that descriptive research uses the questionnaire as a research tool for data collection. In this study, the respondents were required to respond on each item based on the given rating scale: Strongly Agree (4), Agree (3), Disagree (2), and Strongly Disagree (1). The rating scale was presented in even number considering the issues of the existence of the middle category (i.e. „Neither Agree Nor Disagree”, „Indifferent” or "Neutral”) that will prevent the participants from making the real choice (Dornyei, 2003). The writer shared the questionnaires by using Google form. All of the respondents answered the questionnaires by using Google form in their hand phones. Google forms showed the students' responses and percentages for every item asked in the questionnaire.

Before doing the survey, the writer did try out of the questionnaires to find the reliability and validity of the items in the questionnaire. The writer shared Google form with learners as try out in a class.

Table 1 Blue Print of Questionnaires try out based on indicators

\begin{tabular}{lll}
\hline No & \multicolumn{1}{c}{ Indicators } & Number of Questionnaires \\
\hline 1 & Excitement in learning & $1,5,9$ \\
2 & Attention's tendency in learning & $2,6,10$ \\
3 & Students willingness to learn & $3,7,11$ \\
4 & Students active participation in learning & $4,8,12$ \\
& process & \\
\hline
\end{tabular}

Table 2 Validity Questionnaires Try Out

\begin{tabular}{|c|c|c|c|c|c|c|c|c|c|c|c|}
\hline \multicolumn{12}{|c|}{ Significant $5 \%($ rtable $=0.602)$} \\
\hline \multicolumn{12}{|c|}{ r observed $>$ r table (Valid) } \\
\hline \multicolumn{12}{|c|}{ r observed $<\mathrm{r}$ table $($ InValid) } \\
\hline Q1 & Q2 & Q3 & Q4 & Q5 & Q6 & Q7 & Q8 & Q9 & Q10 & Q11 & Q12 \\
\hline \multirow[t]{2}{*}{.792} & -.080 & 0.35 & 0.69 & 0.73 & 0.73 & 0.86 & 0.57 & 0.68 & 0.43 & 0.71 & 0.80 \\
\hline & & 8 & 2 & 0 & 0 & 9 & 7 & 2 & 6 & 8 & 4 \\
\hline valid & $\begin{array}{l}\text { Inval } \\
\text { id }\end{array}$ & $\begin{array}{l}\text { inval } \\
\text { id }\end{array}$ & valid & valid & valid & valid & $\begin{array}{l}\text { inval } \\
\text { id }\end{array}$ & valid & $\begin{array}{l}\text { inval } \\
\text { id }\end{array}$ & valid & valid \\
\hline
\end{tabular}

Table 3 Reliability Questionnaires Try Out

\begin{tabular}{rr}
\hline \multicolumn{2}{c}{ Reliability Statistics } \\
\hline $\begin{array}{c}\text { Cronbach's } \\
\text { Alpha }\end{array}$ & N of Items \\
.842 & 12 \\
\hline
\end{tabular}


Al-Ishlah: Jurnal Pendidikan - ISSN: 2087-949o (p); 2597-940X (e)

Vol. 12, No. 2 (2020)

Based on the table above, the researcher knew that the items of questionnaires are reliable. The value of Cronbach's Alpha was 0.842 . It was higher than the coefficient reliability 0.6. Index reliability can be seen in Table based on Guilford categories.

\section{Table 4 Guilford Categories}

\begin{tabular}{lll}
\hline No & Coefficient correlation & Qualification \\
\hline 1 & $0.91-1.00$ & Very High \\
2 & $0.71-0.90$ & High \\
3 & $0.41-0.70$ & Moderate \\
4 & $0.21-0.40$ & Low \\
5 & Negative- 0.20 & Very low \\
\hline
\end{tabular}

Based on the result of try out, the value of Cronbach's Alpha was 0.842. The category of reliability was High. The test can be stated as reliability. The test would be shared with respondents based on the validity of the questionnaires. The writer also rearrange the number of items of questionnaires, it makes the questionnaires to be a sequence. So, the total item for the questionnaires test is 8 questionnaires.

Table 5 Blue Print of Questionnaires based on indicators

\begin{tabular}{|c|c|c|c|}
\hline No & Indicators & $\begin{array}{l}\text { Number of } \\
\text { Questionnaires }\end{array}$ & $\begin{array}{l}\text { Rearrange the number } \\
\text { item of questionnaires }\end{array}$ \\
\hline 1 & Excitement in learning & $1,5,9$ & $1,3,6$ \\
\hline 2 & $\begin{array}{l}\text { Attention's tendency in } \\
\text { learning }\end{array}$ & 6 & 4 \\
\hline 3 & Students willingness to learn & 7,11 & 5,7 \\
\hline 4 & $\begin{array}{l}\text { Students active participation } \\
\text { in learning process }\end{array}$ & 4,12 & 2,8 \\
\hline
\end{tabular}

\section{FINDINGS AND DISCUSSION}

The result of the research showed that the total rating percentage of learners' interest was $69.98 \%$. It was agreed category. These categories showed the respondents' interest to use blended learning in teaching-learning process. Based on the questionnaires were also analyzed quantitatively to determine the mean and the standards deviation. The writer used SPPS 17 to analyze it. The respondents were asked to rate their agreement to the eighth statements. It is showed a mean score Agree (3). The overall mean is 2.82 and standard deviation is 0.54 .

a. Descriptive analysis

The questionnaire items have been analyzed and the data was calculated in percentages. The result can be referred in Table below: 
Al-Ishlah: Jurnal Pendidikan - ISSN: 2087-9490 (p); 2597-940X (e)

Vol. 12, No. 2 (2020)

Table 6 Percentage of Learners' responds

\begin{tabular}{llllll}
\hline No & $\begin{array}{l}\text { Questionnaires } \\
\text { number }\end{array}$ & $\begin{array}{l}\text { Strongly } \\
\text { Disagree }\end{array}$ & Disagree & Agree & $\begin{array}{l}\text { Strongly } \\
\text { Agree }\end{array}$ \\
\hline 1 & Q1 & $0.6 \%$ & $5.8 \%$ & $83.2 \%$ & $10.3 \%$ \\
2 & Q2 & $2.6 \%$ & $29 \%$ & $63.2 \%$ & $5.2 \%$ \\
3 & Q3 & $1.3 \%$ & $17.4 \%$ & $74.8 \%$ & $6.5 \%$ \\
4 & Q4 & $1.3 \%$ & $16.8 \%$ & $76.1 \%$ & $5.8 \%$ \\
5 & Q5 & $1.3 \%$ & $16.8 \%$ & $76.1 \%$ & $5.8 \%$ \\
6 & Q6 & $0.6 \%$ & $5.8 \%$ & $80.6 \%$ & $12.9 \%$ \\
7 & Q7 & $3.2 \%$ & $33.5 \%$ & $56.8 \%$ & $6.5 \%$ \\
8 & Q8 & $3.9 \%$ & $43.2 \%$ & $49 \%$ & $3.9 \%$ \\
\hline
\end{tabular}

Based on the data above, $83.2 \%$ of respondents agreed looking for on the internet about the material in Q1. Comprehend about Blended Learning (Q2) was 63.2\% agree. $74.8 \%$ agree was responded by watching the learning channel (Q3). To prepare themself by reading material that is shared by the lecturer in learning tool online (Q4), it is $76.1 \%$ agree responded. $76.1 \%$ of respondents agreed to be active in the blended learning process (Q5). 80.6\% of respondents agreed to use applications that is prepared by lecturers (Q6). Be happy in using Blended Learning (Q7) was 56.8 $\%$ agree to respond. $49 \%$ agree to respond from statement be easy to comprehend topic to use Blended Learning (Q8). The total rating percentage of respondents' respond was $69.98 \%$. Categories of the percentages conducted below:

Minimal percentage $25 \%$
Maximal percentage $100 \%$
By 4 scales

\begin{tabular}{cl}
\hline Range percentages & \multicolumn{1}{c}{ Scales } \\
\hline $0-25 \%$ & Strongly disagree \\
$26 \%-50 \%$ & Disagree \\
$51 \%-75 \%$ & Agree \\
$76 \%-100 \%$ & Strongly agree \\
\hline
\end{tabular}

The total rating percentage of learners' interest by using Blended Learning in New Era $69.98 \%$. It was agreed category. These categories showed the respondents interest in Blended Learning. The respondents are agreed by using blended learning in teaching-learning process. They are exciting in learning, attention's tendency in learning, willingness to learn, and be active participations in the learning process. Data collected from the questionnaires were also analyzed quantitatively to determine the mean and the standards deviation. 
Al-Ishlah: Jurnal Pendidikan - ISSN: 2087-949o (p); 2597-940X (e)

Vol. 12, No. 2 (2020)

Table 7 Questionnaires Result: Descriptive statistics

\begin{tabular}{clll}
\hline No & Questionnaires Items Number & Mean & Std. Deviation \\
\hline 1 & Q1 & 3.03 & 0.43 \\
2 & Q2 & 2.70 & 0.60 \\
3 & Q3 & 2.86 & 0.52 \\
4 & Q4 & 2.86 & 0.51 \\
5 & Q5 & 2.86 & 0.51 \\
6 & Q6 & 3.05 & 0.45 \\
7 & Q7 & 2.66 & 0.64 \\
8 & Q8 & 2.52 & 0.63 \\
\hline \multicolumn{2}{l}{ Overall } & 2.82 & 0.54
\end{tabular}

From the table above showed that the overall mean is 2.82 and standard deviation is 0.54 . It meant blended learning on the learning process will help the learners to accommodate their learning style. They have a visual and audio learning style that will be given the opportunity to obtain knowledge is not only currently learning in class face-to -face with the lecturer but they can also get knowledge while outside online or communicating with the lecturer. Then for learners who have a kinesthetic learning style will able to get knowledge when in class face to face. The learners are so excited in the learning by using internet. They are attention's tendency in the learning process, willingness to learn, and be active participation in the Blended Learning process. Hence, blended learning for organizing teaching strategies, teaching delivery, teaching quality will help the lecturer increase the learning attractiveness with lecturers who have been ready to compete to live in the era digital.

Based on the data collected from the questionnaires were also analyzed quantitatively to determine a mean and the standards deviation. The writer used SPPS 17 to analyze it. The respondents were asked to rate their agreement to the eighth statements. It is showed mean score Agree (3). The overall mean is 2.82 and standard deviation is 0.54 . The learners are so excited in blended learning, attention's tendency in blended learning, willingness to learn, and be active participation in learning process. It meant the respondents' interest in using blended learning in the new normal.

\section{CONCLUSION}

From data obtained through the questionnaires distributed to 155 respondents of the second, fourth, sixth semester of Islamic Education Department STAI Hubbulwathan Duri, the researcher could conclude that respondents' interest in the learning process by using Blended Learning. Blended Learning can improve 
Al-Ishlah: Jurnal Pendidikan - ISSN: 2087-949o (p); 2597-940X (e)

Vol. 12, No. 2 (2020)

attraction to the face to face learning process. It can accommodate developments technology without having to leave the face to face learning in class. Blended learning can make the learners continue to learn and follow learning process. It can be a chance for lecturer and learners to be success in learning process.

\section{REFERENCES}

Ainley, M., Hillman, K., \& Hidi, S. (2002). Gender and interest Processes in Response to Literary Texts: Situational and Individual Interest. Learning and Insruction, 12, 411-428.

Dörnyei, Z. 2003.Questionnaires in Second Language Research: Constructing, Administrating and processing. Lawrence Erlbaum Associates Publisher, London.

Garrison, D.R\& Vaughan, N. (2008). Blended Learning in higher education: framework, principles, and guidelines. San Francisco: Jossey- Bass.

Halverson, L.R, Graham, C.R., Spring, K.J, Drysdale,J.S, \& Henrie, C.R (2014). A thematic analysis of the most highly cited scholarship in the first decade of blended learning research. Internet and Higher Education, 20: 20-34.

Hidi, S. (2006). Interest: A Unique Motivational Variable. Educational Research Review. 1, 69-82.

Horn, M.B, \& Staker, H. (2015). Blended: Using Disruptive Innovation to Improve Schools. San Francisco: Jossey-Bass.

Khairani, A., Daud, A., \& Adnan, M. (2020). Students' Acceptance of The Use of Google Classroom as a Platform in Blended Laerning. AL-ISHLAH: Jurnal Pendidikan, 12(1), 1 - 16. doi:https://doi.org/10.35445/alishlah.v12i1.193

Khe, F. H., \& Cheung., W. S. (2014). Using Blended Learning: Evidence-Based Practices. (Springer, Ed.). London.

Kumar, Yosegh Singh. 2006. Fundamental of Research Methodology and Statistic. New Delhi : New Age International

Neumeirer.P. (2005). A closer look at blended learning-parameters for designing a blended learning environment for language teaching. ReCALL, 17 (2), 163178. 
Al-Ishlah: Jurnal Pendidikan - ISSN: 2087-949o (p); 2597-940X (e)

Vol. 12, No. 2 (2020)

Olivia, F. (2011). Teknik Ujian Efektif. Jakarta: Pt. Elex Media Komputindo.

Slameto. (2010). Belajar dan Faktor-faktor yang Mempengaruhinya. Jakarta: PT. Rineka Cipta.

Wang, Z. , \& Adesope, O. (2016). Exploring the Effects of Seductive Details with The Phasemodel of Interest. Learning and Motivation, 55, 65-77. 